The influence of social identity on value perceptions and intention

McGowan, Miriam; Hassan, Louise; Shiu, Edward

Journal of Consumer Behaviour

DOI:

$10.1002 / \mathrm{cb} .1627$

Published: 05/11/2017

Peer reviewed version

Cyswllt i'r cyhoeddiad / Link to publication

Dyfyniad o'r fersiwn a gyhoeddwyd / Citation for published version (APA):

McGowan, M., Hassan, L., \& Shiu, E. (2017). The influence of social identity on value perceptions and intention. Journal of Consumer Behaviour, 16(3), 242-253.

https://doi.org/10.1002/cb.1627

Hawliau Cyffredinol / General rights

Copyright and moral rights for the publications made accessible in the public portal are retained by the authors and/or other copyright owners and it is a condition of accessing publications that users recognise and abide by the legal requirements associated with these rights.

- Users may download and print one copy of any publication from the public portal for the purpose of private study or research.

- You may not further distribute the material or use it for any profit-making activity or commercial gain

- You may freely distribute the URL identifying the publication in the public portal ?

Take down policy

If you believe that this document breaches copyright please contact us providing details, and we will remove access to the work immediately and investigate your claim. 
Title: The influence of social identity on value perceptions and intention

Short title: Social identity and value perceptions

Miriam McGowan ${ }^{a}$, Edward Shiu ${ }^{b}$, Louise M. Hassan ${ }^{c}$

\author{
${ }^{\text {a }}$ Bangor Business School \\ Hen Goleg, Bangor University, College Road, Bangor, LL57 2DG, UK \\ Email: m.mcgowan@bangor.ac.uk
}

Tel: 0044 (0) 1248383628

Corresponding author

Dr Miriam McGowan is a lecturer in Marketing at Bangor Business School. Her research interests are in the consumer research area with a focus on consumers' identification with brands. Most of her research is aimed at understanding how consumers' brand identification drives consumer behaviour and judgments.

${ }^{\mathrm{b}}$ Bangor Business School

Hen Goleg, Bangor University, College Road, Bangor, LL57 2DG, UK

Email: e.shiu@bangor.ac.uk

Prof. Edward Shiu is Professor of Marketing at Bangor Business School. His research interests are in Consumer Research, Social Marketing and Cross-cultural Research. He published in a range of journals including the British Journal of management, European Journal of Marketing, International Marketing Review, Journal of Advertising, Journal of Business Research, Journal of Consumer Affairs, Journal of Marketing Management, Journal of Strategic Marketing, and Psychology \& Marketing.

\author{
${ }^{\mathrm{c}}$ Bangor Business School \\ Hen Goleg, Bangor University, College Road, Bangor, LL57 2DG, UK \\ Email: 1.hassan@bangor.ac.uk
}

Prof. Louise Hassan is Professor of Consumer Psychology at Bangor Business School. Her research interests are international in nature with a focus on transformative consumer research and social marketing. In particular, Prof. Hassan is interested in understanding psychological processes underlying consumption decisions. Prof. Hassan's work has appeared in journals such as the British Journal of management, Journal of Advertising, Journal of Business Research, Journal of Consumer Affairs, Psychology and Marketing, International Marketing Review and the European Journal of Marketing. 


\title{
The influence of social identity on value perceptions and intention
}

\begin{abstract}
Despite much research on consumers' brand-identification researchers remain divided regarding the conceptualisation of the dimensions underlying social identity, and how these dimensions impact marketing outcome variables. Further, previous studies have failed to examine the underlying psychological process driving this effect. The current research is the first to assess the importance of affective social identity as the mediator through which cognitive social identity impacts consumers’ purchase intentions by ways of emotional and social value. Results show that affective social identity mediates the relationship between cognitive social identity and emotional value, where affect is the main driver in the formation of purchase intention. This study highlights the need to model cognitive and affective social identity separately and provides insight into how consumers’ social identification influences their perceptions of identity-linked products.
\end{abstract}

\section{Keywords:}

Social identity, cognitive social identity, affective social identity, consumer value perceptions, purchase intention 


\section{The influence of social identity on value perceptions and intention}

\section{Introduction}

Marketers are becoming increasingly aware of the importance of consumers' identification with a brand or company, as they seek to build committed and meaningful relationships with their customers (Bhattacharya and Sen, 2003; Harmon-Kizer et al., 2013). Consumers use brands to construct and enact their social identity, for example by wearing branded clothes, discussing the brand and its products online, or attending events sponsored by the brand (e.g., Fiedler and Sarstedt, 2014). Social identity refers to the 'part of an individual's self-concept which derives from his knowledge of his membership in a social group (or groups) together with the value and emotional significance attached to that membership’ (Tajfel, 1981: 255).

The social identity approach, first introduced by Tajfel and Turner (1979), has led to extensive research on social identity across disciplines (e.g., Bergami and Bagozzi, 2000; Kang et al., 2015; Lam et al., 2010). Owing to this multi-disciplinary research effort, confusion has arisen as to the conceptualisation and operationalization of social identity, leading to recent calls for further scale development and refinement (Lam et al., 2010). Findings suggest that social identity is multi-dimensional (e.g., Ashmore et al., 2004; Leach et al., 2008). In particular, Johnson et al. (2012) argue for a two dimensional representation of social identity, comprising of a cognitive and an affective dimension. The important role of affect in consumer decision making is well established in literature (e.g., Walsh et al., 2011) with consumers' emotional connection to an organisation and its products playing a central part in driving purchase decisions. Furthermore, marketing practitioners are calling for 'the marketing community to rethink measurement models, as the evidence continues to pour in that emotion plays a role ... in purchase decisions’ (Duboff, 2013: 21). At present, the relationship between cognitive and affective social identity has yet to be fully explored. The first contribution of this research therefore lies in testing the role of affective social identity in 
mediating the impact of cognitive social identity on consumers' value perceptions and purchase intention.

Consumers' identification with a brand is relevant for marketers, as identification positively affects consumers' judgments and behaviours (e.g., Escalas and Bettman, 2005; Forehand et al., 2002; Garry et al., 2008). Thus linking a brand to a social identity will likely result in more positive value perceptions and stronger purchase intentions from strongly identified consumers. However, studies to date (e.g., Lings and Owen, 2007; Madrigal, 2000; White and Argo, 2009) have neglected to examine the underlying psychological process, which this research addresses. Further, researchers (e.g., Gallarza et al., 2011) have called for a richer conceptualisation of customer value beyond quality and price and recommend contributions from the field of psychology among others. The present research reflects this by drawing together the research streams of social identity and perceived value in clarifying how the effects of (cognitive and affective) social identity are channelled through to purchase intention via the mediating role of consumers' value perceptions. The recent paradigm shift in marketing reflects the importance of the value construct, as companies attempt to create customer value (Vargo and Lusch, 2004). Gaining a better understanding of the process underlying the formation of consumers' value perceptions from a social identity perspective is thus novel and relevant for academics and practitioners.

\section{Conceptualisations of social identity}

Consumers hold mental representations of social groups and their members, including beliefs about a group’s norms, values and associated behaviours. Such mental representation is also referred to as the content of a social identity (e.g., Ashforth et al., 2008; Herrmann and Brewer, 2004). Research shows that such mental representations are valued by individuals and are open to revision that gives rise to opportunities for "identity building” (Herrmann and 
Brewer, 2004; La Barbera et al., 2014). However, insufficient attention has been paid regarding the nature and the constituents of such mental representations.

Leach et al. (2008) distinguish between members’ group-level self-definition and their self-investment in the group. Members use their knowledge of the social group to construct a prototypical (ideal) group member (Hogg, 1993; Hogg, 2000). Prototypes are ‘contextspecific fuzzy sets that define and prescribe attitudes, feelings, and behaviours that characterize one group and distinguish it from other groups' (Hogg, 2000: 226). Based on their similarity to a group’s prototypes consumers self-categorise themselves into a social group and use this group as a basis for their self-definition (Leach et al., 2008). Cognitive social identity thus refers to 'cognitive connection between the definition of [a social group] and the definition a person applies to himself or herself' (Wolter and Cronin, 2016: 401), which is in line with Leach et al.’s (2008) self-stereotyping construct. Consumers differ in the degree to which they define themselves in terms of the social group, which shapes their behaviours consistent with the social group (Turner and Oakes, 1986).

The literature suggests identification constitutes more than just cognition; as Harquail (1998: 224) puts it, identification 'engages more than our cognitive self-categorizations and our brains, it engages our hearts'. The emotional component of social identity relates to the self-investment dimension introduced by Leach et al. (2008), in particular to members' satisfaction with their group. The greater individuals experience a change in self-concept in line with the prototype, the greater social and emotional benefits they derive from the group membership. Such benefits arise because social categorisation of self leads to self-attraction and self-esteem (Hogg, 1993). In addition, members’ ongoing cognitive appraisal of their social group is expected to result in positive feelings about the group membership, such as joy or happiness (Ellsworth and Scherer, 2003; Frijda et al., 1989; Lazarus, 1991; Moors, 2010). This effect is explained in detail later. 
Affective social identity measures how positive individuals feel about their group membership (Johnson et al., 2012). While an agreement has been reached regarding the conceptualisation of cognitive social identity, affective social identity has been variously defined resulting in a number of different views (see Table 1). Ellemers et al. (1999) conceptualise affective social identity in terms of members' (affective) commitment to and emotional involvement with their social group. Affective commitment is the 'emotional attachment to, identification with, and involvement in, the organisation’ (Meyer and Allen, 1991: 67). Despite some conceptual similarities between social identity and affective commitment the constructs are distinct (Ashforth et al., 2008). Specifically, commitment represents individuals' positive attitudes toward the organisation that can be formed independently of identification, for instance through satisfaction and trust (Ashforth et al., 2008). Consequently, affective commitment does not equate to affective social identity. Further, most items Ellemers et al. (1999) use to measure affective social identity capture intention to remain in the group, arguably an outcome of identification (Ashforth et al., 2008). Bergami and Bagozzi (2000) also capture affective commitment. With the exception of two items, they capture members' sense of belongingness and attachment to the group.

\section{Insert Table 1 about here}

Lam et al. (2010) measure the strength of customers’ feelings regarding their belongingness to a brand using two items. However, as the items do not capture any specific emotions associated with affective social identity, such as pride or happiness, they likely do not reflect the full complexity of affective social identity. Finally, Leach et al. (2008) refer to group members’ positive feelings about their group membership as ‘satisfaction’, which loads on a different dimension than their cognitive ‘self-stereotyping' construct. Similar to Lam et al. (2010) and Harris and Cameron (2005), Leach et al. (2008) capture individuals’ general positive feeling regarding the group membership, rather than specific emotions elicited by the 
group membership such as pride or happiness. In sum, the social identity literature shows inconsistencies in the conceptualisation and operationalization of the affective social identity component.

Taking into account the above issues with existing conceptualisations of affective social identity, the present research uses the scales developed by Johnson et al. (2012). These authors provide a clear distinction between the two dimensions of social identity, evidencing discriminate validity between them. Cognitive social identity measures individuals' selfcategorisation, that is group members' perceived similarity with the group, while affective social identity captures an 'individual's positive feelings about being one with a group' (Johnson et al., 2012: 1144).

\section{Theory and hypotheses}

\section{Consumers’ social identity}

Whenever consumers' social identity is made salient, for example due to an advertising appeal, consumers receive feedback about their social group or their membership in it. An advertisement may portray the social group in a positive light or consumers may receive compliments on their group membership. Cognitive appraisal theories of emotion predict that such group-related feedback is cognitively appraised to assess the implications for the individual's subjective wellbeing, resulting in emotions such as happiness or joy (e.g., Ellsworth and Scherer, 2003; Frijda et al., 1989; Lazarus, 1991; Moors, 2010). Initial findings suggest that individuals' cognitive appraisal differs as a function of their cognitive social identity. In particular, the extent to which individuals emotionally share in their group's successes and failures depends on their cognitive identification making the group differently important to their self-definition (Crisp et al., 2007; Tajfel, 1978; Wann et al., 1995). In addition, Leach et al. (2008) show that individuals' self-stereotyping predicts participants' guilt over actions taken by their ingroup. It appears that individuals' level of cognitive social 
identity determines how they appraise information, resulting in differential emotional responses.

Taken together, the higher consumers' level of cognitive social identity, the more the social group is linked to their self-concept and the more the social group has positive implications for their wellbeing. For these consumers, any positive information about the group represents positive information about their self, increasing their self-esteem and resulting in positive emotions (e.g., Ellsworth and Scherer, 2003; Smith and Ellsworth, 1985). However, for consumers low in cognitive social identity positive information about the group does not influence how they see themselves and subsequently does not trigger emotions. In support, Johnson et al. (2012: 1135) in their longitudinal study find initial evidence that 'cognitive identification may be a precondition for developing high levels of affective identification, but not vice versa'.

H1. Higher levels of cognitive social identity will lead to higher levels of affective social identity.

\section{Social identity and value perceptions}

Identification with a brand predicts consumers' value perceptions (e.g., He et al., 2012; Kleine III et al., 2009), but research has not taken into account the different dimensions of social identity or value. The conceptual model thus draws together two streams of research linking central concepts in social identity and product-related cognitions (value perceptions and purchase intention). The model posits that consumers' value perceptions act as a mediator, through which consumers' identification with a social group impacts their motivation to purchase identity-linked products. Value perceptions represent consumers’ evaluation of their trade-off between the costs of acquiring a product and the benefits they receive from said product (Sánchez-Fernández and Iniesta-Bonillo, 2007). 
Owing to the complexity of the value construct a number of alternative conceptualisations exist. As such, research has conceptualised value as a one-dimensional construct, measuring 'the consumer's overall assessment of the utility of a product based on perceptions of what is received and what is given' (Zeithaml, 1988: 14). According to this perspective consumers engage in a cognitive trade-off between costs (price) and benefits they receive from a product (Zeithaml, 1988). Others such as Sheth et al. (1991) assert that multiple value dimensions impact consumer decision making with consumer perceptions of these value dimensions making different contributions depending on the consumption context. Babin et al. (1994) distinguish between utilitarian (products’ cognitive, task-oriented value) and hedonic value (products’ affective, experiential value). Mattson (1991) proposes emotional, practical (functional) and logical (rational, abstract) value dimensions, which are further extended in Holbrook’s (1999) typology of perceived consumer value. Sweeney and Soutar (2001) distinguish between an emotional, social, quality/performance and price value dimension. Overall, value perceptions appear to have a tangible/functional and an intangible/ experiential component, although research has focused mainly on the tangible (quality and price) value dimensions (see Sánchez-Fernández and Iniesta-Bonillo, 2007 for an overview). However, as brands provide self-definitional benefits, which go beyond such utilitarian benefits (e.g., Escalas and Bettman, 2003), these tangible value dimensions do not capture the underlying motivations regarding products that carry strong symbolic meanings (Holbrook and Hirschman, 1982). This study therefore models consumers’ perceived social and emotional value as outcomes of consumers' social identity. Sweeney and Soutar (2001: 211) define social value as 'the utility derived from the product's ability to enhance social self-concept', while emotional value captures the 'utility derived from the feelings or affective states that a product generates'. 
Consumers hold knowledge structures containing information on attitudes, behaviours, goals, and emotions, which characterize a certain social identity (Coleman and Williams, 2013; Kleine III et al., 1993). If members of a social group use a brand, the brand becomes part of this content (Escalas and Bettman, 2005). Brands can therefore derive meaning from the social group they are associated with, which is transferred onto the user (McCracken, 1986). Objects associated with the social group represent an opportunity for consumers to express their group membership. In this way social categories are substantiated. In parallel, research has shown that identification results in more positive product evaluations, as well as increased purchase intention for identity-linked products (e.g., Forehand et al., 2002; White and Dahl, 2007).

Consumers high in cognitive social identity perceive themselves as prototypical group members, and align their attitudes, feelings and behaviours with the group prototype (Hogg, 2000). Consumers align themselves with prototypical group members to avoid subjective uncertainty, an aversive state that they are motivated to rectify (Hogg, 2000). Furthermore, consumers can expect prototypical group members to evaluate products linked to the group favourably, as the positive group-evaluation transfers onto the product (Gawronski et al., 2007; Reed II et al., 2012). Taken together, products that signal a linkage to the group prototype will be perceived attitudinally and emotionally more favourable by these consumers.

H2. Higher levels of cognitive social identity will lead to higher levels of perceived (a) emotional value and (b) social value to be derived from the identity-linked product. The identity-association principle (Reed II et al., 2012) predicts that when a stimulus, such as a product, becomes associated with a social identity held by a consumer an affective transfer takes place from the social identity to the product. The affective transfer results in a more favourable evaluation of and positive response to the product (Reed II et al., 2012). 
Findings by Brendl et al. (2005) further suggest that this transfer is feeling based. As a result, for consumers high in affective social identity, products linked to the social identity will offer social and emotional benefits, due to the affective transfer from the social identity to the product. It follows that the higher consumers' affective social identity, the more social and emotional value they expect to derive of the identity-linked product.

H3. Higher levels of affective social identity will lead to higher levels of perceived (a) emotional value and (b) social value to be derived from the identity-linked product. Consumers use brands to enact and communicate their social identity (Kleine III et al., 1993) to satisfy their need for a stable self-view. The resulting sense of coherence is important for individuals to interpret their surrounding and social interactions (Swann et al., 2003). Knowing who one is helps determine how to interact with others, and to predict how others will react to oneself. Consumers thus strategically use products or brands as identity cues, which allow them to communicate a consistent self-view (Swann et al., 2003). As such, an identity-linked product will be more useful as an identity cue for consumers high in cognitive social identity than for consumers low in cognitive social identity. Those high in cognitive social identity have a higher motivation to communicate their social identity and therefore higher purchase intention for a product that allows them to do so.

H4. Higher levels of cognitive social identity will lead to higher levels of intention to purchase identity-linked products.

Past research has highlighted the importance of emotions for explaining consumers' behavioural intentions in settings such as retail outlets, shopping malls, hotels, and restaurants (e.g., El Sayed et al., 2003; see also Elliott, 1998). Smith et al. (2007) find that group emotions, meaning emotions arising as a function of being a group member, predict a range of ingroup-supporting and outgroup avoiding behaviours (e.g., ingroup solidarity). This finding is due to emotions holding action tendencies, which may result in either approach or 
avoidance related behaviours. Positive emotions such as happiness or joy have an approachdirected action tendency (Frijda et al., 1989). Consumers high in affective social identity are therefore expected to wish to engage in behaviours that make them feel closer to their social group, such as the purchase of identity-linked products to help enact their social identity.

H5. Higher levels of affective social identity will lead to higher levels of intention to purchase identity-linked products.

Value perceptions help understand important aspects of consumer behaviour such as purchase intention (e.g., Zhou and Wong, 2008). Studies evidence a strong impact of emotional value on purchase intention (Sweeney and Soutar, 2001; Turel et al., 2007; Williams and Soutar, 2009), customer satisfaction, and loyalty (Walsh et al., 2014). However, empirical evidence regarding the impact of social value on behavioural intentions is mixed, with significant findings by Sweeney and Soutar (2001) but not by others (e.g., Turel al., 2007; Williams and Soutar, 2009). On balance, it is argued that

H6. Higher levels of (a) emotional value and (b) social value will lead to higher levels of purchase intention.

\section{Methodology}

Two studies were conducted to test the hypothesized conceptual model. In Study 1, a sample of 225 US consumers (43\% female, average age of 43 years) was collected using Amazon’s Mechanical Turk (MTurk). The study examined consumers’ identification with Apple users, in the context of their intention to purchase a (fictitious) T-shirt branded with the Apple logo. In Study 2, a sample of 311 students (61\% female, average age of 21 years) was collected at a UK university to cross-validate the findings by varying social group and country. The second study focused on students' identification with their Academic School as used in prior studies (e.g., Johnson et al., 2012). Respondents fill in a paper and pencil questionnaire, in the context of purchasing a hoodie branded by the Academic School, which was available for 
sale. For both studies the measurement scales were adapted from existing scales (Table 2) based on a 7-point Likert response scale.

\section{Insert Table 2 about here}

\section{Results}

A two-step modelling approach was used in the analyses (Anderson and Gerbing, 1988). Initially confirmatory factor analysis was used to assess the reliability and validity of the scales in the measurement model then the hypotheses were tested based on structural equation modelling with the software package Amos (Version 22). Indirect effects were assessed using bootstrapping analyses (with 5,000 bootstrap samples) as recommended by Shrout and Bolger (2002). All reported p-values are two-tailed.

\section{Study 1}

In line with conventional benchmarks (Hair et al., 1998), the overall fit of the measurement model is good $\left(\chi^{2}=274.80\right.$, d.f. $=125, p<0.001$, Comparative Fit Index [CFI $]=0.97$, Tucker Lewis Index $[\mathrm{TLI}]=0.96$, Root Mean Square Error of Approximation $[$ RMSEA $]=0.073$, Normed Fit Index $[\mathrm{NFI}]=0.94$, Akaike Information Criterion $[\mathrm{AIC}]=366.80)$. All constructs have alpha and construct reliability values above 0.80 , with the lowest average variance extracted (AVE) of 0.71 (Table 2). All indicators load significantly $(p<0.001)$ on their respective constructs, with standardized factor loadings of 0.66 or above. These findings affirm the convergent validity of the measures (Fornell and Larcker, 1981). Table 3 shows the descriptive statistics and correlations between the constructs for studies 1 and 2. Discriminant validity is established across the five constructs in accordance with Fornell and Larcker (1981) as the squared correlation between each pair of constructs is smaller than the associated AVE values. Potential concerns regarding common method bias were addressed by employing two approaches recommended by Podsakoff et al. (2003). Specifically, the survey instrument contained three separate sections with instructions that forced an 
interruption to subjects’ responses. Secondly, Harmon’s single factor test assessed the presence of common method bias showing no concerns as the single factor model yields greatly decreased fit $\left(\chi^{2}=2259.46\right.$, d.f. $=135, p<0.001, \mathrm{CFI}=0.54, \mathrm{TLI}=0.48, \mathrm{NFI}=0.53$, RMSEA $=0.27$, AIC $=2367.46)$.

The structural model shows similarly good fit statistics $\left(\chi^{2}=274.80\right.$, d.f. $=125, p<0.001$, $\mathrm{CFI}=0.97, \mathrm{TLI}=0.96, \mathrm{NFI}=0.94, \mathrm{RMSEA}=0.073, \mathrm{AIC}=366.80)$. Figure 1 shows an overview of the results. Cognitive social identity is positively related to affective social identity ( $(=0.59, p<0.001$ ), therefore $H 1$ is supported. $H 2 a, H 2 b$ and $H 4$ are also supported as cognitive social identity positively impacts emotional value ( $(=0.16, p=0.03)$, social value $(\beta=0.46, p<0.001)$, as well as purchase intention $(\beta=0.12, p=0.008)$. Affective social identity has a significant impact on emotional value ( $ß=0.45, p<0.001$ ), but not on social value $(\beta=0.15, p=0.06)$, or purchase intention $(\beta=0.08, p=0.09)$. H3a is therefore supported, but $H 3 b$ and $H 5$ are not. Of the two value dimensions, only emotional value has a significant impact on purchase intention ( $(=0.79, p<0.001$ ), thus $H 6 a$ is supported, but $H 6 b$ is not. The $\mathrm{R}^{2}$ value of 0.80 shows that overall the proportion of variance explained in purchase intention is very high. In sum, of the nine direct relationships hypothesized six are supported.

\section{Insert Table 3 and Figure 1 about here}

The conceptual model suggests seven mediating processes (M1 to $M 7$ - see Table 4). Examination of mediating effects using bootstrapping shows that affective social identity mediates the relationship between cognitive social identity and emotional value $(M 1)$ with a significant indirect effect $(\beta=0.26$, CI: $0.17,0.36)$. However, affective social identity does not mediate the relationship between cognitive social identity and social value (M2), because the bootstrapping results show the indirect effect is not significant with the $95 \%$ biascorrected confidence interval crossing zero $(\beta=0.09, \mathrm{CI}$ - $-0.002,0.18)$. Emotional value fully 
mediates the effect of affective social identity on purchase intention (M3), as the indirect effect ( $\beta=0.35$ ) is significant (CI: $0.22,0.47)$, while the direct effect is not $(p=0.09)$. Due to the insignificant direct effect of social value on purchase intention $(p=0.91)$ social value cannot mediate the impact of cognitive or affective social identity on purchase intention (M4 and M7). Affective social identity also does not have a significant direct effect on purchase intention $(p=0.09)$, thus does not mediate the relationship between cognitive social identity and purchase intention (M5). Finally, cognitive social identity has a significant indirect effect ( $\beta=0.38$ ) on purchase intention through affective social identity and emotional value (M6: CI: $0.26,0.50)$. The direct effect of cognitive social identity on purchase intention is significant ( $\beta=0.12$, CI: $0.03,0.22$ ), this (serial) relationship is partially mediated by affective social identity and emotional value. The $\mathrm{R}^{2}$ value of 0.80 shows that, the overall proportion of variance explained in purchase intention is very high.

\section{Insert Table 4 about here}

Figure 2 depicts one possible alternative model with social identity conceptualised as a second-order latent construct in line with Bagozzi and Dholakia (2006) and Cheung and Lee (2010). This model has a worse model fit than the proposed model $\left(\chi^{2}=311.26\right.$, d.f. $=128, p$ $<0.001, \mathrm{CFI}=0.96, \mathrm{TLI}=0.95, \mathrm{NFI}=0.94, \mathrm{RMSEA}=0.08, \mathrm{AIC}=397.26)$. Further, the results are similar to those of the proposed model, in that social identity positively impacts emotional value $(\beta=0.75 p<0.001)$ and social value $(\beta=0.76, p<0.001)$, while emotional value impact purchase intention $(\beta=0.65, p<0.001)$, but social value does not $(p=0.09)$.

\section{Insert Figure 2 about here}

\section{Study 2}

Study 2 also yielded a good model fit $\left(\chi^{2}=260.72\right.$, d.f. $=125, p<0.001$, CFI $=0.97$, TLI $=$ 0.96, NFI $=0.94$, RMSEA $=0.059$, AIC $=352.72$ ) for the confirmatory factor analysis, which decreases greatly using Harmon's single factor test $\left(\chi^{2}=2140.12\right.$, d.f. $=135, p<$ 
0.001, $\mathrm{CFI}=0.52, \mathrm{TLI}=0.46, \mathrm{NFI}=0.51, \mathrm{RMSEA}=0.219, \mathrm{AIC}=2248.12)$. The structural model also shows good fit statistics $\left(\chi^{2}=260.72\right.$, d.f. $=125, p<0.001$, CFI $=0.97$, TLI $=$ 0.96, NFI $=0.94$, RMSEA $=0.059$, AIC $=352.72)$. Similar to Study 1 the design of the survey instrument resulted in interruptions to subjects' responses. Common method bias is therefore not an issue. As in Study 1, the high AVE values in comparison to the square of the correlations between pairs of constructs evidenced discriminant validity for this second sample.

Cognitive social identity has a positive direct effect on affective social identity $(\beta=0.30, p$ $<0.001)$, emotional value $(\beta=0.20, p=0.003)$, and social value $(\beta=0.59, p<0.001)$. Therefore, $H 1, H 2 a$, and $H 2 b$ are supported. Affective social identity has a significant impact on emotional value $(\Omega=0.38, p<0.001)$, but not on social value $(\beta=0.03, p=0.60)$, meaning $H 3 a$ is supported, while $H 3 b$ is not. Further neither cognitive social identity $(\beta=$ $0.03, p=0.57)$, affective social identity $(\beta=-0.07, p=0.12)$, nor social value $(\beta=-0.09, p=$ 0.18) have a direct effect onto purchase intention, thus $H 4, H 5$, and $H 6 b$ are not supported. However, H6a is supported, as emotional value has a direct effect on purchase intention $(\beta=$ $0.92, p<0.001)$.

Similar to Study 1, affective social identity partially mediates the impact of cognitive social identity on emotional value (M1: $\beta=0.11, \mathrm{CI}$ : $0.07,0.18)$, but not the relationship between cognitive social identity and social value (M2: CI: -0.02, 0.04). The bootstrapping results also show that emotional value fully mediates the impact of affective social identity on purchase intention, as the indirect effect is significant (M3: $\beta=0.34$; CI: $0.24,0.46$ ) but the direct effect is not $(p=0.12)$. As is Study 1 the lack of direct effect of social value on purchase intention ( $p=0.18$ ) prevents social value acting as a mediator between social identity and purchase intention (M4 and $M 7$ ). Affective social identity cannot mediate the effect of cognitive social identity on purchase intention (M5), due to the lack of significant 
direct effect between affective social identity and purchase intention $(p=0.12)$. Finally, cognitive social identity has a significant indirect effect $(\beta=0.21)$ on purchase intention through affective social identity and emotional value (M6: CI: 0.09, 0.33). As the direct effect of cognitive social identity on purchase intention is not significant $(\beta=0.03, p=0.57)$, this (serial) relationship is fully mediated by affective social identity and emotional value. The $\mathrm{R}^{2}$ value of 0.73 shows that, the overall proportion of variance explained in purchase intention is very high.

Similar to the findings of Study 1, the fit of the alternative model is also worse than the fit of the proposed model $\left(\chi^{2}=311.01\right.$, d.f. $=128, p<0.001$, CFI $=0.96$, TLI $=0.95$, NFI $=$ 0.93, RMSEA $=0.068$, AIC $=397.01)$. In line with the proposed model, social identity has a positive effect on emotional value $(\beta=0.66, p<.001)$ and social value $(\beta=.89, p<0.001)$. However, social identity does not affect purchase intention, either directly $(p=0.61)$ or indirectly (CI: $-1.19,5.52)$.

Taken together the two samples provide support for a serial mediation of cognitive social identity on purchase intention, through affective social identity and emotional value. As can be seen in Figure 1 the results for both studies are consistent with the exception of H4, which is supported by Study 1 but not Study 2 .

\section{Discussion}

This research sets out to clarify the psychological process whereby (cognitive and affective) social identity results in marketing relevant outcomes by examining the mediating role of affective social identity and value perceptions. The findings lend support to the conceptual model. Specifically, affective social identity mediates the effect of cognitive social identity on emotional value, and emotional value mediates the effects of social identity on purchase 
intention. It is important to examine these mediation processes to understand the underlying mechanism through which cognitive social identity impacts purchase intention.

The research makes two major theoretical contributions. Firstly, cognitive social identity and affective social identity are shown to be two distinct constructs, which affect emotional and social value differently. Traditionally social identity has been conceptualised as a unidimensional construct (e.g., Tajfel and Turner, 1979), but more recent work (e.g., Ashmore et al., 2004; Johnson et al., 2012; Leach et al., 2008) suggests that social identity is multidimensional. Despite this little is known about the relationship between cognitive and affective social identity and tests of their discriminant validity are scarce (Wolter and Cronin, 2016).

Secondly, this is the first study to empirically assess the role of affective social identity as the mediator, through which cognitive social identity affects consumers’ product-related cognitions, as suggested by the identity association principle (Reed et al., 2012). Past research has studied the affective transfer from the personal identity to a product (Perkins and Forehand, 2012) but has not examined the mediating role of affective social identity. Results across both studies support the identity association principle whereby affective social identity mediates the effect of cognitive social identity onto emotional value and purchase intention. This finding suggests that past findings on identity-linked attitudes, perceptions and behaviours (e.g., Ahearne et al., 2005; Kim et al., 2010; Madrigal, 2000; White et al., 2012; Winterich et al., 2009; Zhang and Khare, 2009) should be reconsidered in light of their failure to account for the mediating role of affective social identity.

Not all hypothesized relationships are supported. H5 was not supported as the effect of affective social identity on purchase intention is fully mediated by emotional value, hence the insignificant direct effect. Taken at face value, one might question the $H 4$ and $H 5$ findings where cognitive but not affective social identity has a significant impact on intention to 
purchase the identity-linked product. One possible reason lies with the consumers' motive for identification. Consumers identify with social groups in order to feel better (self-esteem hypothesis; Tajfel and Turner, 1979) or to reduce uncomfortable social uncertainty (uncertainty reduction hypothesis; Hogg, 2000). Johnson et al. (2012) suggest that the two motives are associated with the two social identity dimensions. As such, self-esteem is associated with affective social identity, which captures how consumers feel about their group membership. Uncertainty-reduction is a motive underlying why consumers depersonalise in favour of the group prototype. Consumers high in cognitive social identity are motivated to behave in a manner consistent with prototypical attitudes, perceptions and behaviours in order to reduce subjective uncertainty (Hogg, 2000). Products linked to the social identity are likely consistent with the group prototype and therefore afford such opportunity for uncertainty reduction. However, such identity-linked products do not directly result in self-esteem enhancement through purchase alone. As a consequence, the study finds a lack of direct effect between affective social identity and purchase intention (H5).

Contrary to $H 3 b$ affective social identity does not impact social value. Consequently, affective social identity does not mediate the impact of cognitive social identity on social value (M2), and social value does not mediate the relationship between affective social identity and purchase intention (M4). The failure to support $H 3 b$ may be because even though consumers high in affective social identity feel positive about their group membership, they do not perceive identity-linked products as necessary for gaining social approval. However, the findings show a significant relationship between cognitive social identity and social value. Social value captures a product's ability to project the social self-concept associated with a social group. This self-concept is most consistent with that of individuals high in cognitive social identity, who have depersonalised strongly. Further, given the mixed results reported in the literature regarding the impact of social value on behavioural intention (e.g., 
Antón et al., 2014; Turel et al., 2007; Williams and Soutar, 2009), the failure to support H6b is not surprising.

One possible explanation of why social value does not impact purchase intention may lie in the conceptualisation and role of the social value construct in relation to the other perceived value constructs and the overall meaning of perceived value. Sweeney and Soutar (2001) reported much lower correlations between the social value dimension and the other three value dimensions. Further, prior research shows that social value does not relate to consumers’ overall value perceptions (e.g., Turel et al., 2007; Walsh et al., 2014). Together these findings suggest that the meaning and role of the social value construct within consumer decision making needs to be reconsidered.

The results are robust as the second study, using a different social identity in a different country, yields very similar results leading to the same findings. Nevertheless, future research should replicate these findings, perhaps using different types of social groups. This research examined existing social groups but individuals may regard brands associated with aspirational groups differently, as they help satisfy different psychological needs, compared to non-aspirational groups (Escalas and Bettman, 2003). To a certain extent, this study can be considered cross-cultural, due to the use of samples from different individualistic cultures (the US and the UK). Future work should test whether the results and findings of the current research still hold in more collectivistic countries such as China or Portugal (The Hofstede Centre, 2014).

Along with its important theoretical contribution to existing research on identity-linked products, this study has important practical implications for marketing. As many products become increasingly interchangeable in mature markets (e.g., breakfast cereals), marketers must find new and innovative ways of connecting with their consumers. Linking products to (established) social groups such as ethnicity, lifestyle choices, football clubs, or a 
region/district helps marketers engage with consumers, strengthen relationships, and adds value to brands. The present study shows that linking a product to consumers' social group adds social and emotional value to said products. Moreover, consumers who strongly identify with a social group are more willing to purchase a product associated with it and thus resulting in an increase in company revenues. Most importantly, this effect appears affect driven. Marketers may therefore wish to increase consumers' affective social identity, as a way to increase consumers’ purchase intention. For example, advertisements may portray members of the particular social group positively or use emotional appeals and experiential marketing to increase consumers' affective social identity regarding the brand. In store, customers could be encouraged to interact with each other, for example to share positive stories about their experience with the brand. In contrast, if marketers wish to influence consumers' evaluations of the social value of their product, they should focus on consumers' similarity to the group, rather than highlighting the positive emotions associated with group membership. Finally, marketers may wish to make consumers’ social identity more salient, especially at the point of purchase. For example, this can be achieved by making it possible to purchase products within an online brand community, which by its nature makes consumers' brand specific social identity salient.

\section{References}

Ahearne, M, Bhattacharya, CB, Gruen, T. 2005. Antecedents and Consequences of Customer-Company Identification: Expanding the Role of Relationship Marketing. Journal of Applied Psychology 90(3): 574-585. doi: 10.1037/0021-9010.90.3.574

Anderson, JC, Gerbing, DW. 1988. Structural equation modeling in practice: A review and recommended two-step approach. Psychological Bulletin 103(3): 411-423. doi: 10.1037/0033-2909.103.3.411 
Antón, C, Camarero, C, Gil, F. 2014. The culture of gift giving: what do consumers expect from commercial and personal contexts? Journal of Consumer Behaviour 13(1): 31-41. doi: $10.1002 / c b .1452$

Ashforth, BE, Harrison, SH, Corley, KG. 2008. Identification in organizations: an examination of four fundamental questions. Journal of Management 34(3): 325-374. doi: $10.1177 / 0149206308316059$

Ashmore, RD, Deaux, K., McLaughlin-Volpe, T. 2004. An organizing framework for collective identity: articulation and significance of multidimensionality. Psychological Bulletin 130(1): 80-114. doi: 10.1037/0033-2909.130.1.80

Babin, BJ, Darden, WR, Griffin, M. 1994. Work and/or fun: measuring hedonic and utilitarian shopping. Journal of Consumer Research 20(4): 644-656. doi: 10.1086/209376

Bagozzi, RP, Dholakia, UM. 2006. Antecedents and purchase consequences of customer participation in small group brand communities. International Journal of Research in Marketing 23(1): 45-6. doi:10.1016/j.ijresmar.2006.01.005

Bergami, M, Bagozzi, RP. 2000. Self-categorization, affective commitment and group selfesteem as distinct aspects of social identity in the organization. British Journal of Social Psychology 39(4): 555-577. doi: 10.1348/014466600164633

Bhattacharya, CB, Sen, S. 2003. Consumer-company identification: a framework for understanding consumers' relationships with companies. Journal of Marketing 67(2): 7688. doi: http://dx.doi.org/10.1509/jmkg.67.2.76.18609

Brendl, CM, Chattopadhyay, A, Pelham, BW, Carvallo, M. 2005. Name letter branding: Valence transfers when product specific needs are active. Journal of Consumer Research 32(3): 405-415. doi: http://dx.doi.org/10.1086/497552

Cheung, CMK, Lee, MKO. 2010. A theoretical model of intentional social action in online social networks. Decision Support Systems, 49(1): 24-30. doi:10.1016/j.dss.2009.12.006 
Coleman, NV, Williams, P. 2013. Feeling like my self: emotion profiles and social identity. Journal of Consumer Research 40(2): 203-222. doi: 10.1086/669483

Crisp, RJ, Heuston, S, Farr, MJ, Turner, RN. 2007. Seeing red or feeling blue: Differentiated intergroup emotions and ingroup identification in soccer fans. Group Processes \& Intergroup Relations 10(1): 9-26. doi: 10.1177/1368430207071337

Duboff, RS. 2013. Making better marketing decisions: a left-brain argument for the right brain. Marketing News, June: 19-24.

Ellemers, N, Kortekaas, P, Ouwerkerk, JW. 1999. Self-categorisation, commitment to the group and group self-esteem as related but distinct aspects of social identity. European Journal of Social Psychology 29(2-3): 371-389. doi: 10.1002/(SICI)10990992(199903/05)29:2/3<371::AID-EJSP932>3.0.CO;2-U

Elliott, R. 1998. A model of emotion-driven choice. Journal of Marketing Management 14(13): 95-108. doi: 10.1362/026725798784959408

Ellsworth, PC, Scherer, KR. 2003. Appraisal processes in emotion, in Handbook of affective sciences, Richard J. Davidson, Klaus R. Scherer, H. Hill Goldsmith (eds), New York, NY: Oxford University Press; 572-595.

El Sayed, IM, Farrag, DA, Belk, RW. 2003. The effects of physical surroundings on Egyptian consumers’ emotional states and buying intentions. Journal of International Consumer Marketing 16(1): 5-27. doi: 10.1300/J046v16n01_02

Escalas, JE, Bettman, JR. 2003. You are what they eat: the influence of reference groups on consumers' connections to brands. Journal of Consumer Psychology 13(3): 339-348. doi: 10.1207/S15327663JCP1303_14

Escalas, JE, Bettman, JR. 2005. Self-construal, reference groups, and brand meaning. Journal of Consumer Research, 32(3): 378-389. doi: 10.1086/497549 
Fiedler, M, Sarstedt, M. 2014. Influence of community design on user behaviors in online communities. Journal of Business Research 67(11): 2258-2268. doi:10.1016/j.jbusres.2014.06.014

Forehand, MR, Deshpandé, R, Reed II, A. 2002. Identity salience and the influence of differential activation of the social self-schema on advertising response. Journal of Applied Psychology, 87(6), 1086-1099. doi: 10.1037/0021-9010.87.6.1086

Fornell, C, Larcker, DF. 1981. Evaluating structural equation models with unobservable variables and measurement error. Journal of Marketing Research 18(1): 39-50. doi: $10.2307 / 3151312$

Frijda, NH, Kuipers, P, ter Schure, E. 1989. Relations among emotion, appraisal, and emotional action readiness. Journal of Personality and Social Psychology 57(2): 212-228. doi: 10.1037/0022-3514.57.2.212

Gallarza, MG, Gil-Saura, I, Holbrook, MB. 2011. The value of value: further excursions on the meaning and role of customer value. Journal of Consumer Behaviour 10(4): 179-191. doi: 10.1002/cb.328

Garry, T, Broderick, AJ, Lahiffe, K. 2008. Tribal motivation in sponsorship and its influence on sponsor relationship development and corporate identity. Journal of Marketing Management 24(9-10): 959-977. doi: 10.1362/026725708X381993

Gawronski, B., Bodenhausen, G., Becker, AP. 2007. I like it, because I like myself: Associative self-anchoring and post-decisional change of implicit evaluations. Journal of Experimental Social Psychology 43: 221-232. doi:10.1016/j.jesp.2006.04.001

Hair, JF, Anderson, RE, Tatham, RL, Black, WC. 1998. Multivariate data analysis (5 th ed.). Englewood Cliffs, NJ: Prentice Hall. 
Harmon-Kizer, TR, Kumar, A, Ortinau, D, Stock, J. 2013. When multiple identities compete: the role of centrality in self-brand connections. Journal of Consumer Behaviour 12(6): 483-495. doi: 10.1002/cb.1449

Harquail, C.V. 1998. Organizational identification and the 'whole person': integrating affect, behavior, and cognition, in Identity in organizations: Building theory through conversations, David A. Whetten, Paul C.Godfrey (eds.), Sage, Thousand Oaks, CA; 223231.

Harris, GE, Cameron, JE. 2005. Multiple dimensions of organizational identification and commitment as predictors of turnover intentions and psychological well-being. Canadian Journal of Behavioral Science 37(3): 159-169. doi: 10.1037/h0087253

He, H, Li, Y, Harris, L. 2012. Social identity perspective on brand loyalty. Journal of Business Research 65(5): 648-657. doi: 10.1016/j.jbusres.2011.03.007

Herrmann, RK, Brewer, MB. 2004. Identities and institutions: Becoming European in the EU, in Transnational identities: Becoming European in the EU, Richard K. Herrmann, Thomas Risse, Marilynn B. Brewer (eds.). New York, NY: Rowman \& Littlefield; 1-22.

Hogg, MA. 1993. Group cohesiveness: a critical review and some new directions. European Review of Social Psychology 4(1): 85-111. doi: 10.1080/14792779343000031

Hogg, MA. 2000. Subjective uncertainty reduction through self-categorization: a motivational theory of social identity processes. European Review of Social Psychology 11(1): 223255. doi: $10.1080 / 14792772043000040$

Holbrook, MB. 1999. Introduction to consumer value, in Consumer Value: A framework for analysis and research, Morris B Holbrook (ed.). Routledge, London; 1-28.

Holbrook, MB, Hirschman, EC. 1982. The experiential aspects of consumption: consumer fantasies, feelings, and fun. Journal of Consumer Research 9(2): 132-140. doi: $10.1086 / 208906$ 
Johnson, MD, Morgeson, FP, Hekman, DR. 2012. Cognitive and affective identification: Exploring the links between different forms of social identification and personality with work attitudes and behavior. Journal of Organizational Behavior 33(8): 1142-1167. doi: 10.1002/job.1787

Kang, J., Alejandro, TB, Groza, MD. 2015. Customer-company identification and the effectiveness of loyalty programs. Journal of Business Research 68(2): 464-471. doi: 10.1016/j.jbusres.2014.06.002

Kim, T, Chang, K, Ko, YJ. 2010. Determinants of organisational identification and supportive intentions. Journal of Marketing Management 26(5-6): 413-427. doi: $10.1080 / 02672570903485022$

Kleine, RE, Kleine, SS, Brunswick, GJ. 2009. Transformational consumption choices: building an understanding by integrating social identity and multi-attribute attitude theories. Journal of Consumer Behaviour 8(1): 54-70. doi: 10.1002/cb.273

Kleine III, RE, Kleine, SS, Kernan, JB. 1993. Mundane consumption and the self: a socialidentity perspective. Journal of Consumer Psychology 2(3): 209-235. doi: 10.1016/S10577408(08)80015-0

Kunst-Wilson, WR, Zajonc, RB. 1980. Affective discrimination of stimuli that cannot be recognized. Science 207(4430): 557-558. doi: 10.1126/science.7352271

La Barbera, F, Ferrara, PC, Boza, M. 2014. Where are we coming from versus who we will become: The effect of priming different contents of European identity on cooperation. International Journal of Psychology 49(6): 480-487. doi: 10.1002/ijop.12073

Lam, SK, Ahearne, M, Hu, Y, Schillewaert, N. 2010. Resistance to brand switching when a radically new brand is introduced: A social identity perspective. Journal of Marketing 74(6): 128-146. doi: http://dx.doi.org/10.1509/jmkg.74.6.128

Lazarus, RS. 1991. Emotion and adaptation. New York: Oxford University Press. 
Lazarus, RS, McCleary, RA. 1951. Autonomic discrimination without awareness: A study of subception. Psychological Review 58(2): 113-122. http://dx.doi.org/10.1037/h0054104

Leach, CW, van Zomeren, M, Zebel, S, Vliek, ML, Pennekamp, SF, Doosje, B, Ouwerkerk, JW, Spears, R. 2008. Group-level self-definition and self-investment: A hierarchical (multicomponent) model of in-group identification. Journal of Personality and Social Psychology 95(1): 144-165. doi: 10.1037/0022-3514.95.1.144

Lings, IN, Owen, KM. 2007. Buying a sponsor's brand: the role of affective commitment to the sponsored team. Journal of Marketing Management 23(5/6): 483-496. doi: 10.1362/026725707X212784

Madrigal, R. 2000. The influence of social alliances with sports teams on intentions to purchase corporate sponsors' products. Journal of Advertising 29(4): 13-24. doi: 10.1080/00913367.2000.10673621

Mattson, J. 1991. Better business by the Abc of values. Lund: Studdentlitteratur.

McCracken, G. 1986. Culture and consumption: a theoretical account of the structure and movement of the cultural meaning of consumer goods. Journal of Consumer Research 13(1): 71-84. doi: 10.1086/209048

Meyer, JP, Allen, NJ. 1991. A three-component conceptualization of organizational commitment. Human Resource Management Review 1(1): 61-89. doi: 10.1016/10534822(91)90011-Z

Moors, G. 2010. Theories of emotion causation: a review, in Cognition and emotion: Reviews of current research and theories, Jan de Houwer, Dirk Hermans (eds.). Taylor and Francis: Hoboken; 1-37. 
Perkins, AW, Forehand, MR. 2012. Implicit self-referencing: The effect of nonvolitional selfassociation on brand and product attitude. Journal of Consumer Research 39(1): 142-156. doi: 10.1086/662069

Podsakoff, PM, MacKenzie, SM, Lee, JY, Podsakoff, NP. 2003. Common method variance in behavioral research: a critical review of the literature and recommended remedies. Journal of Applied Psychology 88(5): 879-903. doi: 10.1037/0021-9010.88.5.879

Reed II, A, Forehand, MR, Puntoni, S, Warlop, L. 2012. Identity-based consumer behavior. International Journal of Research in Marketing 9: 310-321. doi:

10.1016/j.ijresmar.2012.08.002

Sánchez-Fernández, R, Iniesta-Bonillo, MA. 2007. The concept of perceived value: a systematic review of the research. Marketing Theory 7(4): 427-451. doi: $10.1177 / 1470593107083165$

Sheth, JN, Newman, BI, Gross, BL. 1991. Why we buy what we buy: A theory of consumption values. Journal of Business Research 22(2): 159-170. doi: 10.1016/01482963(91)90050-8

Shrout, PE, Bolger, N. 2002. Mediation in experimental and nonexperimental studies: new procedures and recommendations. Psychological Methods 7(4): 422-445. doi: 10.1037/1082-989X.7.4.422

Smith, CA, Ellsworth, PC. 1985. Patterns of cognitive appraisal in emotion. Journal of Personality and Social Psychology 48(4): 813-838. doi: 10.1037/0022-3514.73.1.63

Smith, ER, Seger, CR, Mackie, DM. 2007. Can emotions be truly group level? Evidence regarding four conceptual criteria. Journal of Personality and Social Psychology 93(3): 431-446. doi: 10.1037/0022-3514.93.3.431 
Swann Jr., WB, Rentfrow, PJ, Guinn, JS. 2003. Self-Verification: the search for coherence, in Handbook of self and identity, Mark R. Leary, June P. Tangney (eds.) The Guildford Press: New York, London; 367-383.

Sweeney, JC, Soutar, GN. 2001. Consumer perceived value: The development of a multiple item scale. Journal of Retailing 77(2): 203-220. doi: 10.1016/S0022-4359(01)00041-0

Tajfel, H. 1978. Differentiation between social groups. London: Academic Press.

Tajfel, H. 1981. Human groups and social categories: Studies in social psychology. Cambridge University Press: Cambridge.

Tajfel, H., Turner, JC. 1979. An integrative theory of intergroup conflict, The social psychology of intergroup relations, William G. Austin, Stephen Worchel (eds.). Brooks/Cole: Monterey, CA; 33-47.

The Hofstede Centre. 2014. Portugal. Available at http://geert-hofstede.com/portugal.html [accessed on 07 April 2014].

Turel, O, Serenko, A, Bontis, N. 2007. User acceptance of wireless short messaging services: deconstructing perceived value. Information and Management 44(1): 63-73. doi: 10.1016/j.im.2009.10.002

Turner, JC, Oakes, PJ. 1986. The significance of the social identity concept for social psychology with reference to individualism, interactionism and social influence. British Journal of Social Psychology 25(3): 237-252. doi: 10.1111/j.2044-8309.1986.tb00732.x

Vargo, SL, Lusch, RL. 2004. Evolving to a new dominant logic for marketing. Journal of Marketing 68(1): 1-17. doi: http://dx.doi.org/10.1509/jmkg.68.1.1.24036

Walsh, G, Shiu, E, Hassan, LM. 2014. Replicating, validating, and reducing the length of the consumer perceived value scale. Journal of Business Research 67(3): 260-267. doi: 10.1016/j.jbusres.2013.05.012 
Walsh, G, Shiu, E, Hassan, LM, Michaelidou, N, Beatty, SE. 2011. Emotions, storeenvironmental cues, store-choice criteria, and marketing outcomes. Journal of Business Research 64(7): 737-744. doi: 10.1016/j.jbusres.2010.07.008

Wann, DL, Hamlet, M, Wilson, T, Hodges, J. 1995. Basking in reflected glory, cutting off reflected failure, and cutting off future failure: The importance of group identification. Social Behavior and Personality 23(4): 377-388.

White, K, Argo, JJ. 2009. Social identity threat and consumer preferences. Journal of Consumer Psychology 19(3): 313-325. doi: 10.1016/j.jcps.2009.03.007

White, K, Argo, JJ, Sengupta, J. 2012. Dissociative versus associative responses to social identity threat: the role of consumer self-construal. Journal of Consumer Research 39(4): 704-719. doi: 10.1086/664977

White, K, Dahl, DW. 2007. Are all outgroups created equal? Consumer identity and dissociative influence. Journal of Consumer Research 34(4): 525-536. doi:10.1086/520077

Williams, P, Soutar, GN. 2009. Value, satisfaction and behavioral intentions in an adventure tourism context. Annals of Tourism Research 36(3): 413-438. doi: 10.1016/j.annals.2009.02.002

Winterich KP, Mittal, V, Ross Jr, WT. 2009. Donation behavior toward in-groups and outgroups: The role of gender and moral identity. Journal of Consumer Research 36(2): 199214.

Wolter, J, Cronin Jr., JJ. 2016. Re-conceptualizing cognitive and affective customer-company identification: The role of self-motives and different customer-based outcomes. Journal of the Academy of Marketing Science, 44(3): 397-413. doi: 10.1007/s11747-014-0421-6

Zajonc, RB. 1980. Feeling and thinking: Preferences need no inferences. American Psychologist 35(2): 151-175. doi: http://dx.doi.org/10.1037/0003-066X.35.2.151 
Zeithaml, VA. 1988. Consumer perceptions of price, quality, and value: A means-end model and synthesis of evidence. Journal of Marketing 52(3): 2-22. doi: 10.2307/1251446

Zhang, Y, Khare, A. 2009. The impact of accessible identities on the evaluation of global versus local products. Journal of Consumer Research 36(3): 524-537. doi: $10.1086 / 598794$

Zhou, L, Wong, A. 2008. Exploring the influence of product conspicuousness and social compliance on purchasing motives of young Chinese consumers for foreign brands. Journal of Consumer Behaviour 7: 470-483. doi: 10.1002/cb.265 
Table 1

Overview of (affective) social identity conceptualisations

\begin{tabular}{|c|c|c|c|}
\hline $\begin{array}{l}\text { Construct name } \\
\text { and author(s) }\end{array}$ & $\begin{array}{l}\text { Definition (where } \\
\text { provided) }\end{array}$ & Scale items & Critique of measure \\
\hline $\begin{array}{l}\text { Affective } \\
\text { commitment } \\
\text { Bergami and } \\
\text { Bagozzi (2000) }\end{array}$ & $\begin{array}{l}\text { Joy dimension } \\
\text { '[H]appiness arising from } \\
\text { the organization as a social } \\
\text { category' (p. } 560 \text { ) } \\
\\
\text { Love dimension } \\
\text { '[E]motional attraction or } \\
\text { affection towards the } \\
\text { organization as a social } \\
\text { category' (p. } 560 \text { ) }\end{array}$ & $\begin{array}{l}\text { Affective commitment (Joy) } \\
\text { - I would be very happy to spend the rest of my career } \\
\text { with Camst. } \\
\text { - I enjoy discussing Camst with people outside it. } \\
\text { - I really feel as Camst's problems are my own. } \\
\text { - Camst has great deal of personal meaning for me. } \\
\text { Affective commitment (Love) } \\
\text { - I do not feel like part of the family at Camst. } \\
\text { - I do not feel emotionally attached to Camst. } \\
\text { - I do not feel a strong sense of belonging to Camst. }\end{array}$ & $\begin{array}{l}\text { Items } 1 \text { and } 2 \text { of the affective } \\
\text { commitment (joy) subscale capture } \\
\text { positive feelings resulting from } \\
\text { group membership. However items } 3 \\
\text { and } 4 \text { measure the importance of the } \\
\text { organisation for the individual's self- } \\
\text { concept, rather than affective social } \\
\text { identity. In addition, the items of the } \\
\text { love subscale capture members' } \\
\text { feeling of belongingness/ } \\
\text { commitment to the organisation. } \\
\text { Affective commitment differs from } \\
\text { (affective) social identity. }\end{array}$ \\
\hline $\begin{array}{l}\text { Affective } \\
\text { commitment } \\
\text { Ellemers et al. } \\
(1999)\end{array}$ & $\begin{array}{l}\text { '[The] sense of emotional } \\
\text { involvement with the } \\
\text { group' (p. 372) }\end{array}$ & $\begin{array}{l}\text { - I would like to continue working with my group. } \\
\text { - I dislike being a member of the other group. } \\
\text { - I would rather belong to the other group. }\end{array}$ & $\begin{array}{l}\text { Affective commitment captures } \\
\text { commitment to the group, measuring } \\
\text { members' intention to remain within } \\
\text { the group, making it a behavioural } \\
\text { outcome variable of social identity. }\end{array}$ \\
\hline
\end{tabular}




\begin{tabular}{|c|c|c|c|}
\hline $\begin{array}{l}\text { Construct name } \\
\text { and author(s) }\end{array}$ & $\begin{array}{l}\text { Definition (where } \\
\text { provided) }\end{array}$ & Scale items & Critique of measure \\
\hline $\begin{array}{l}\text { In-group affect } \\
\text { Harris and } \\
\text { Cameron (2005) }\end{array}$ & $\begin{array}{l}\text { '[T]he subjective } \\
\text { evaluation of a social } \\
\text { group and the subsequent } \\
\text { emotions (e.g., feeling } \\
\text { glad or regretful) this } \\
\text { engenders' (p. 160) }\end{array}$ & $\begin{array}{l}\text { - In general, I am glad to be a member of this } \\
\text { organization. } \\
\text { - I often regret that I am a member of this } \\
\text { organization. } \\
\text { - I don't feel good about being a member of this } \\
\text { organization. } \\
\text { - Generally, I feel good when I think about myself as } \\
\text { a member of this organization. }\end{array}$ & $\begin{array}{l}\text { The in-group affect subscale captures } \\
\text { members' general feelings about } \\
\text { their group membership (affective } \\
\text { social identity), but could be } \\
\text { extended by including additional } \\
\text { specific emotions such as pride. }\end{array}$ \\
\hline $\begin{array}{l}\text { Affective social } \\
\text { identity } \\
\text { Johnson et al. } \\
\text { (2012) }\end{array}$ & $\begin{array}{l}\text { '[I]ndividual's positive } \\
\text { feelings about being one } \\
\text { with a group' (p. 1144) }\end{array}$ & $\begin{array}{l}\text { - I feel happy to be a student in the university. } \\
\text { - I am proud to be a student in the university. } \\
\text { - It feels good to be a student in the university. } \\
\text { - If I were forced to leave the university, I would be } \\
\text { very disappointed. }\end{array}$ & \\
\hline $\begin{array}{l}\text { Affective } \\
\text { customer brand } \\
\text { identification } \\
\text { Lam et al. } \\
\text { (2010) }\end{array}$ & $\begin{array}{l}\text { '[The] affective } \\
\text { investment in the } \\
\text { awareness and evaluations } \\
\text { [of customers' } \\
\text { belongingness to a brand]' } \\
\text { (p. 130) }\end{array}$ & $\begin{array}{l}\text { - When someone praises [brand], it feels like a } \\
\text { personal compliment. } \\
\text { - I would experience an emotional loss if I had to stop } \\
\text { using [brand]. }\end{array}$ & $\begin{array}{l}\text { Affective customer-brand } \\
\text { identification taps into customers' } \\
\text { emotions regarding their } \\
\text { belongingness to a brand, but does } \\
\text { not capture any specific emotions. } \\
\text { Additional items are needed to } \\
\text { reflect the full complexity of } \\
\text { affective social identity. }\end{array}$ \\
\hline $\begin{array}{l}\text { Satisfaction } \\
\text { Leach et al. } \\
\text { (2008) }\end{array}$ & $\begin{array}{l}\text { '[U]nambiguous feelings } \\
\text { of satisfaction’ (p. 147) }\end{array}$ & $\begin{array}{l}\text { - I am glad to be [In-group]. } \\
\text { - I think that [In-group] have a lot to be proud of. } \\
\text { - It is pleasant to be [In-group]. } \\
\text { - Being [In-group] gives me a good feeling. }\end{array}$ & Similar to Johnson et al. (2012) \\
\hline
\end{tabular}


Table 2

Measurement items and validity assessment

\begin{tabular}{|c|c|c|c|c|}
\hline Construct & $\beta$ & $\alpha$ & CR & AVE \\
\hline Cognitive social identity & & 0.94 & 0.94 & 0.79 \\
\hline (Johnson et al., 2012) & & {$[0.81]$} & {$[0.83]$} & {$[0.56]$} \\
\hline $\begin{array}{l}\text { Your self-identity is based in part on being a user of Apple } \\
\text { products. }\end{array}$ & $0.93[0.83]$ & & & \\
\hline $\begin{array}{l}\text { Using Apple products is very important to your sense of } \\
\text { who you are. }\end{array}$ & $0.96[0.86]$ & & & \\
\hline Your sense of self overlaps with the identity of Apple. & $0.92[0.75]$ & & & \\
\hline $\begin{array}{l}\text { If Apple were criticized, it would influence how you } \\
\text { thought about yourself. }\end{array}$ & $0.72[0.48]$ & & & \\
\hline Affective social identity & & 0.88 & 0.91 & 0.71 \\
\hline (Johnson et al., 2012) & & {$[0.82]$} & {$[0.85]$} & {$[0.60]$} \\
\hline You feel happy to be an Apple user. & $0.86[0.84]$ & & & \\
\hline You are proud to be an Apple user. & $0.87[0.88]$ & & & \\
\hline It feels good to be an Apple user. & $0.95[0.86]$ & & & \\
\hline $\begin{array}{l}\text { If you were forced to stop using Apple products, you } \\
\text { would be very disappointed. }\end{array}$ & $0.66[0.45]$ & & & \\
\hline Emotional value & & 0.96 & 0.99 & 0.95 \\
\hline (Sweeney and Soutar, 2001) & & {$[0.91]$} & {$[0.95]$} & [0.83] \\
\hline $\begin{array}{l}\text { A T-shirt branded with the Apple logo ... } \\
\text { - is one that you would enjoy wearing. } \\
\text { - would make you want to wear it. } \\
\text { - is one that you would feel relaxed about wearing. }\end{array}$ & $\begin{array}{l}0.98[0.91] \\
0.97[0.91] \\
0.87[0.81]\end{array}$ & & & \\
\hline Social value & & 0.94 & 0.97 & 0.89 \\
\hline (Sweeney and Soutar, 2001) & & {$[0.91]$} & {$[0.91]$} & {$[0.73]$} \\
\hline $\begin{array}{l}\text { A T-shirt branded with the Apple logo would... } \\
\text { - help you feel acceptable. } \\
\text { - improve the way you are perceived. } \\
\text { - make a good impression on other people. } \\
\text { - give its owner social approval. }\end{array}$ & $\begin{array}{l}0.87[0.84] \\
0.93[0.88] \\
0.88[0.86] \\
0.88[0.84]\end{array}$ & & & \\
\hline $\begin{array}{l}\text { Purchase intention } \\
\text { (White et al., 2012) }\end{array}$ & & $\begin{array}{c}0.95 \\
{[0.93]}\end{array}$ & $\begin{array}{c}0.95 \\
{[0.94]}\end{array}$ & $\begin{array}{c}0.88 \\
{[0.83]}\end{array}$ \\
\hline $\begin{array}{l}\text { You would... } \\
\text { - be likely to purchase a T-shirt branded by Apple. } \\
\text { - be willing to buy a T-shirt branded by Apple. } \\
\text { - likely make a T-shirt branded by Apple one of your first } \\
\text { choices in this product category. }\end{array}$ & $\begin{array}{l}0.99[0.96] \\
0.92[0.95] \\
0.89[0.82]\end{array}$ & & & \\
\hline \multicolumn{5}{|c|}{$\begin{array}{l}\text { Notes: Items phrased as Study } 1 \text { (Apple). All items measured using seven-point scales anchored } \\
\text { by } 0=\text { Strongly disagree and } 6=\text { Strongly agree; } \beta \text { : standardized beta coefficient; } \alpha \text { : Cronbach's } \\
\text { alpha; AVE: average variance extracted; CR: construct reliability. } n=225 \text { [Main study, Apple] } \\
(n=311 \text { [Study 2, Academic School]); results of Study } 2 \text { in square brackets. }\end{array}$} \\
\hline
\end{tabular}


Table 3.

Descriptive statistics and correlations between the constructs

\begin{tabular}{|c|c|c|c|c|c|}
\hline Construct & Mean (SD) & 1 & 2 & 3 & 4 \\
\hline 1. Cognitive SI & $1.50(1.44)[2.80(1.15)]$ & $-[-]$ & & & \\
\hline 2. Affective SI & $3.90(1.28)[4.90(0.84)]$ & $0.60[0.20]$ & $-[-]$ & & \\
\hline 3. Emotional value & $2.60(1.80)[3.80(1.32)]$ & $0.40[0.30]$ & $0.50[0.40]$ & $-[-]$ & \\
\hline 4. Social value & $2.00(1.50)[2.90(1.36)]$ & $0.50[0.60]$ & $0.40[0.20]$ & $0.60[0.50]$ & $-[-]$ \\
\hline 5. Purchase intention & $2.00(1.81)[3.60(1.55)]$ & $0.50[0.20]$ & $0.50[0.30]$ & $0.90[0.80]$ & $0.60[0.50]$ \\
\hline
\end{tabular}

Notes: $\mathrm{SD}=$ standard deviation, $\mathrm{SI}=$ social identity; results of Study 2 in square brackets; all correlations are significant at $p<0.01$ (2-tailed)

Table 4

Overview of mediating effects

\begin{tabular}{ll}
\hline Mediating pathway & Full/Partial/No \\
\hline M1. Cognitive SI $\rightarrow$ Affective SI $\rightarrow$ Emotional value & Partial [Partial] \\
M2. Cognitive SI $\rightarrow$ Affective SI $\rightarrow$ Social value & No [No] \\
M3. Affective SI $\rightarrow$ Emotional value $\rightarrow$ Purchase intention & Full [Full] \\
M4. Affective SI $\rightarrow$ Social value $\rightarrow$ Purchase intention & No [No] \\
M5. Cognitive SI $\rightarrow$ Affective SI $\rightarrow$ Purchase intention & No [No] \\
M6. Cognitive SI $\rightarrow$ Affective SI $\rightarrow$ Emotional value $\rightarrow$ Purchase intention & Partial [Full] \\
M7. Cognitive SI $\rightarrow$ Affective SI $\rightarrow$ Social value $\rightarrow$ Purchase intention & No [No]
\end{tabular}

Notes: Results of Study 2 in square brackets; SI = social identity 
Figure 1. Results of Studies 1 and 2

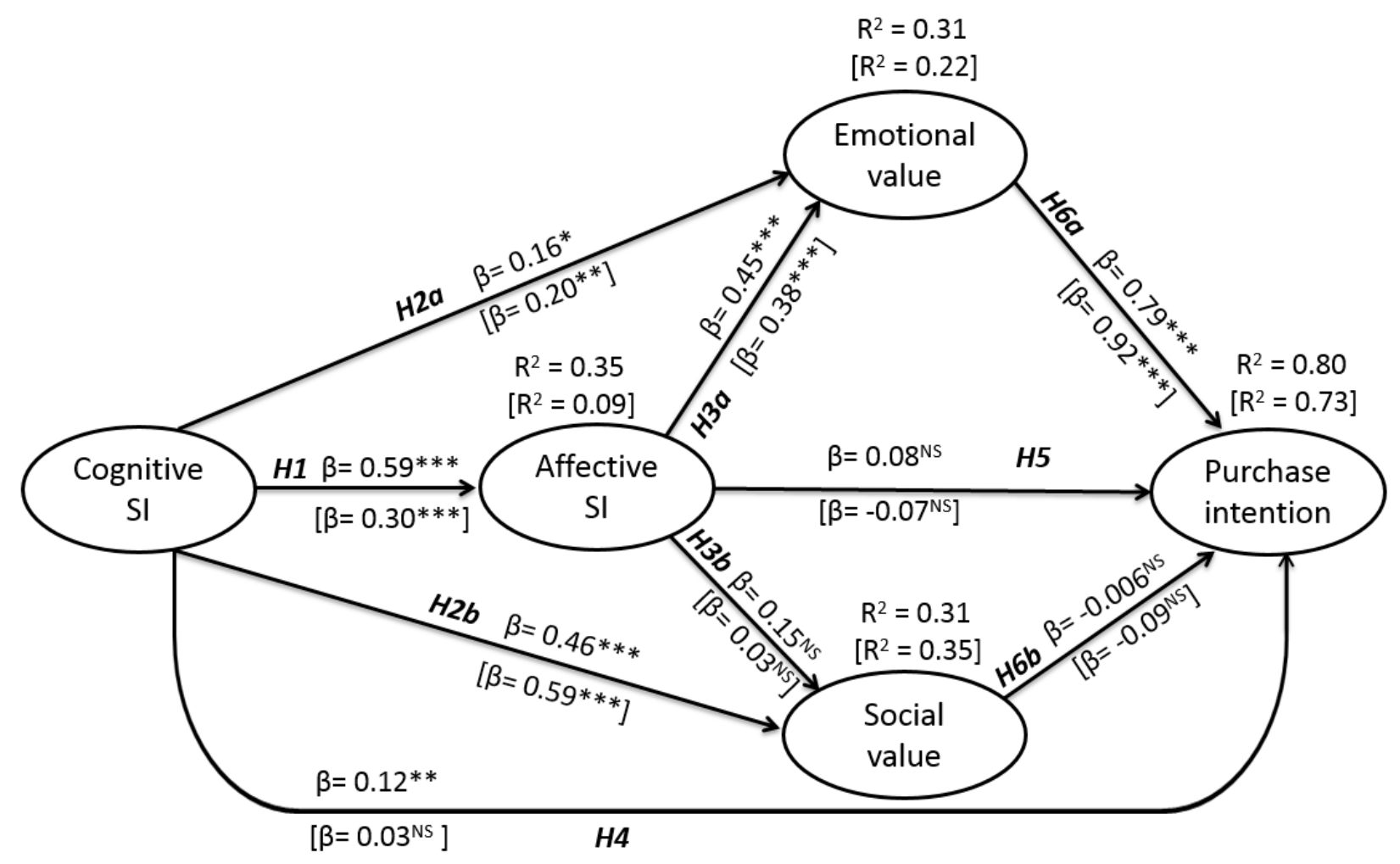

Notes: ${ }^{*} p<0.05,{ }^{* *} p<0.01, * * * p<0.001$, NS = not significant; SI= social identity; results of study 2 in square brackets

Figure 2 Alternative model

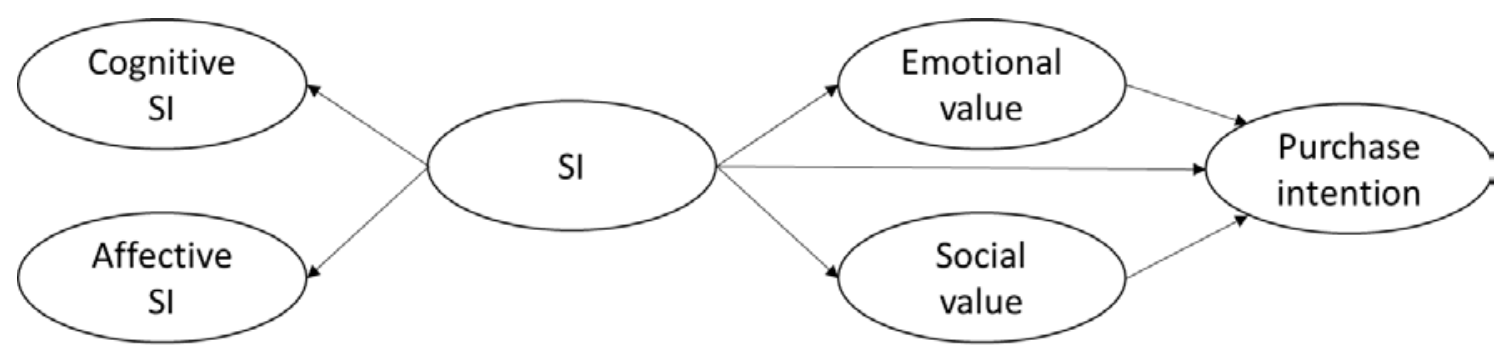

Notes: SI = social identity 